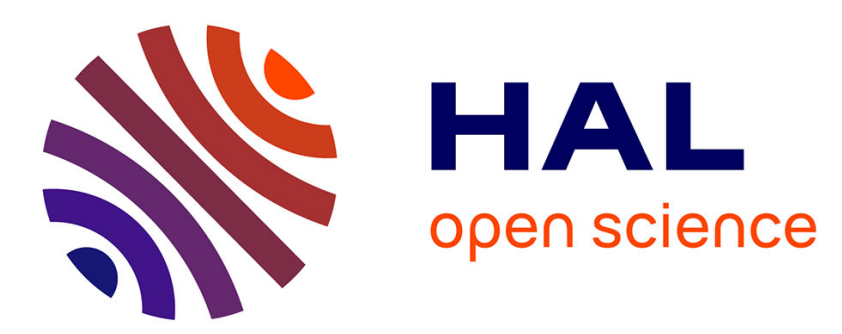

\title{
Lowering iron chlorosis of olive by soil application of iron sulfate or siderite
}

Juan Cañasveras, Antonio Sánchez-Rodríguez, María Campillo, Vidal Barrón, José Torrent

\section{- To cite this version:}

Juan Cañasveras, Antonio Sánchez-Rodríguez, María Campillo, Vidal Barrón, José Torrent. Lowering iron chlorosis of olive by soil application of iron sulfate or siderite. Agronomy for Sustainable Development, 2014, 34 (3), pp.677-684. 10.1007/s13593-013-0191-4 . hal-01234811

\section{HAL Id: hal-01234811 https://hal.science/hal-01234811}

Submitted on 27 Nov 2015

HAL is a multi-disciplinary open access archive for the deposit and dissemination of scientific research documents, whether they are published or not. The documents may come from teaching and research institutions in France or abroad, or from public or private research centers.
L'archive ouverte pluridisciplinaire HAL, est destinée au dépôt et à la diffusion de documents scientifiques de niveau recherche, publiés ou non, émanant des établissements d'enseignement et de recherche français ou étrangers, des laboratoires publics ou privés. 


\title{
Lowering iron chlorosis of olive by soil application of iron sulfate or siderite
}

\author{
Juan Carlos Cañasveras • Antonio Rafael Sánchez-Rodríguez • \\ María Carmen del Campillo • Vidal Barrón • José Torrent
}

Accepted: 8 October 2013 / Published online: 24 October 2013

(C) INRA and Springer-Verlag France 2013

\begin{abstract}
About $70 \%$ of the olive is grown on calcareous soils in Spain, most of which can induce iron $(\mathrm{Fe})$ chlorosis. The main symptoms are interveinal yellowing of the young leaves, leaf necrosis, and reduction of leaf and shoot size, which can lead to major yield losses. Several strategies have been used to avoid $\mathrm{Fe}$ chlorosis such as the application of $\mathrm{Fe}$ chelates, but they are expensive. Here, we studied the effectiveness of synthetic siderite $\left(\mathrm{FeCO}_{3}\right)$ and $\mathrm{Fe}$ sulfate injected in the form of suspension/solution into the soil for correcting $\mathrm{Fe}$ chlorosis in olives. Experiments were established in spring 2009 for four growing seasons in 'Manzanilla,' 'Ocal,' 'Arbequina,' and 'Picual' orchards. The treatments were injections of (1) a siderite suspension; (2) a Fe sulfate solution supplied with $\mathrm{K}_{2} \mathrm{SO}_{4}$ to make up for the $\mathrm{K}$ present in the siderite suspension; (3) a $\mathrm{K}_{2} \mathrm{SO}_{4}$ solution, named Control-K; and (4) water, named Control-0. At the start of the experiment, the suspensions or solutions were injected into the soil at 10-20 points around the tree at the depth of maximum root density. Results show that $\mathrm{Fe}$ chlorosis was alleviated in 'Manzanilla' and 'Picual' since leaf chlorophyll concentration (as estimated by the soil plant analysis development (SPAD) value) in the trees treated with siderite or Fe sulfate was increased by 4-7\% relative to the control trees, and leaf weight was increased by 6-9\%, but not in the 'Arbequina' and 'Ocal' trees. This finding was explained by higher available $\mathrm{Fe}$ in Arbequina and Ocal soils. The antichlorosis effect of iron sulfate was persistent and slightly higher than that of siderite. Both iron sulfate and siderite are not susceptible to leaching due to the low solubility of $\mathrm{Fe}$ oxide phases. Thus, a single application of these fertilizers
\end{abstract}

J. C. Cañasveras $(\bowtie) \cdot$ A. R. Sánchez-Rodríguez •

M. C. del Campillo · V. Barrón · J. Torrent

Departamento de Agronomía, Universidad de Córdoba, Edificio C4, Campus de Rabanales, 14071 Córdoba, Spain

e-mail: g02casaj@uco.es constitutes a promising alternative to other Fe fertilizers, which require more than one application per year.

Keywords Iron chlorosis · Iron deficiency $\cdot$ Siderite $\cdot$ Iron sulfate $\cdot$ Calcareous soils $\cdot$ Olive tree

\section{Introduction}

Iron $(\mathrm{Fe})$ deficiency chlorosis, which is characterized by interveinal yellowing of the leaf, is commonplace in plants growing on calcareous soils (Tagliavini and Rombolà 2001; Abadía et al. 2011). Iron chlorosis sensu stricto is often associated with other symptoms (such as leaf necrosis and reduction of leaf and shoot size) and can result in important yield losses (Fig. 1). Increasing Fe availability can be achieved through several strategies, including the supply of $\mathrm{Fe}$ compounds either to the soil near the root system, to the tree aerial part as foliage sprays, or by trunk or branch injections. Also, selection of tolerant cultivars is effective to prevent the problems of $\mathrm{Fe}$ deficiency in both annual and perennial species (Alcántara et al. 2003).

Correcting Fe chlorosis is difficult and costly. Iron chelates applied to the plant or to the soil are widely used for controlling this deficiency because they are an effective source of Fe (Álvarez-Fernández et al. 2004). Important progresses have been made on the preparation and use of the Fe chelates and natural Fe-complex fertilizers (Abadía et al. 2011; Lucena 2006); however, they are generally costly and have the important limitation of being easily washed from the soil. In addition, Fe chelates can trigger nutritional disorders because they can chelate $\mathrm{Mn}$ and reduce plant uptake of this element (Sánchez-Alcalá et al. 2012a).

Many different inorganic Fe sources have been used to alleviate $\mathrm{Fe}$ chlorosis. Insoluble products are generally ineffective in the short term, although good results have been 


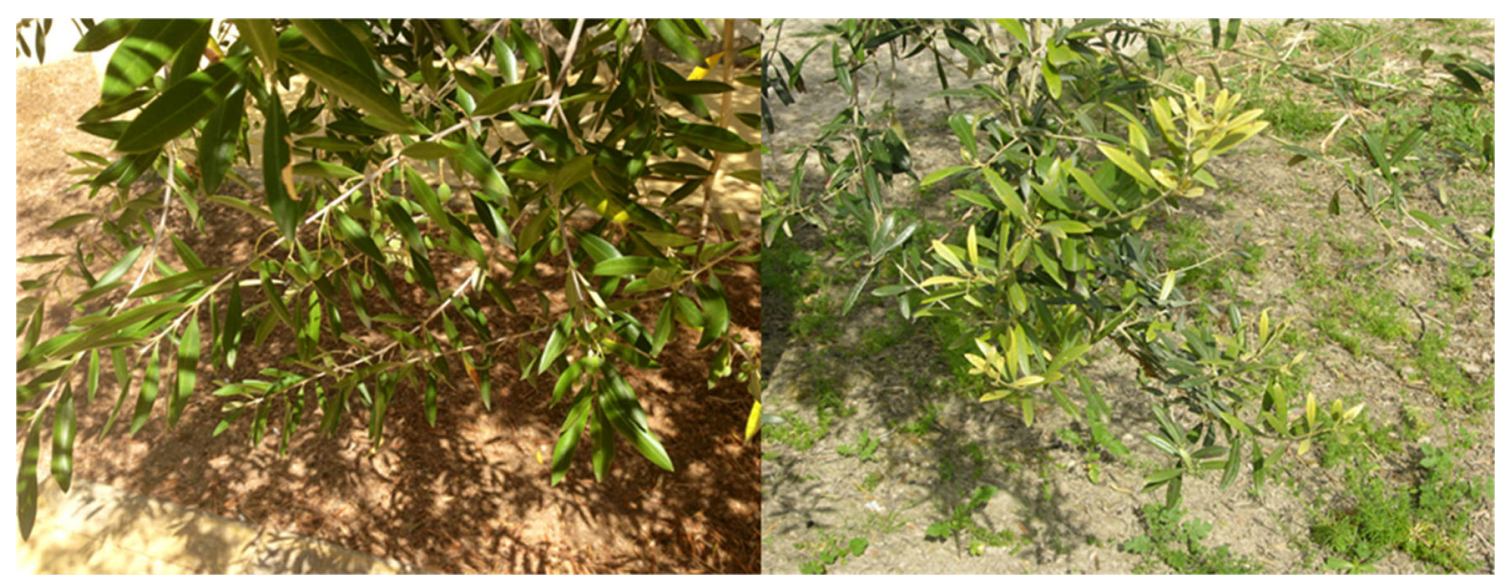

Fig. 1 The photo on the left corresponds to a healthy olive, and the one on the right, an olive with iron chlorosis. The main symptoms are interveinal yellowing of the young leaves, leaf necrosis, and reduction of leaf and shoot size, and can result in important yield losses

obtained with some of these products if they are thoroughly mixed with the soil. This is the case with vivianite, an Fe(II) phosphate $\left[\mathrm{Fe}_{3}\left(\mathrm{PO}_{4}\right)_{2} \cdot 8 \mathrm{H}_{2} \mathrm{O}\right]$ (Rosado et al. 2002; Díaz et al. 2010), and siderite, an $\mathrm{Fe}(\mathrm{II})$ carbonate $\left(\mathrm{FeCO}_{3}\right)$ (SánchezAlcalá et al. 2012a, b). The efficacy of these products is related to their ability to react with the soil carbonate to produce poorly crystalline Fe oxides (Roldán et al. 2002; SánchezAlcalá et al. 2012a), which are considered to be the main source of Fe to the plant (Loeppert and Hallmark 1985; del Campillo and Torrent 1992; de Santiago and Delgado 2006). The problem of these two salts is that they should be applied in the form of a suspension that must be continuously stirred to prevent uneven distribution of the product in the soil.

$\mathrm{Fe}(\mathrm{II})$ sulfate is commonly used in foliar fertilization, spread in granulated form over the soil surface, or applied in the form of mixtures with organic materials. In most cases, the residual effects are limited; in addition, full recovery is not expected in foliar sprays (Tagliavini et al. 2000). The poor results obtained with these soluble inorganic $\mathrm{Fe}$ salts are attributed to their almost immediate transformation into insoluble Fe oxides. Obviously, this strongly limits mass flow and diffusion of $\mathrm{Fe}$ to the plant roots not close to the point where the fertilizer granule or solution is placed.

In summary, correction of $\mathrm{Fe}$ chlorosis is difficult, costly, and often yields poor results. A need thus exists for effective, cheap, and environmentally friendly Fe fertilizers. To the authors' knowledge, no experiments have been made in which a dilute Fe sulfate has been applied to a large volume of soil in order to place the products resulting from its transformation in the soil close to plant roots. The objectives of the present paper were to assess the effectiveness of a dilute Fe sulfate solution injected into the soil to correct $\mathrm{Fe}$ chlorosis in olive and compare it with a suspension of siderite, a product that has proven to be effective for olive growing on highly calcareous soils but is more expensive and difficult to prepare than the Fe sulfate solution.

\section{Materials and methods}

\subsection{Plant and soil materials}

The four experimental orchards were planted with 3-year-old 'Manzanilla,' 3-year-old 'Arbequina,' 14-year-old 'Ocal,' and 7-year-old 'Picual' olive trees and were located near the localities of Gilena $\left(37^{\circ} 14^{\prime} \mathrm{N}, 4^{\circ} 54^{\prime} \mathrm{W}\right)$, Aldea Quintana $\left(37^{\circ} 43^{\prime} \mathrm{N}, 4^{\circ} 48^{\prime} \mathrm{W}\right)$, Aldea Quintana $\left(37^{\circ} 43^{\prime} \mathrm{N}, 4^{\circ} 48^{\prime} \mathrm{W}\right)$, and Baena $\left(37^{\circ} 38^{\prime} \mathrm{N}, 4^{\circ} 15 \mathrm{~W}\right)$, respectively, in Andalusia, southern Spain. In all orchards, olive trees exhibited clear symptoms of Fe chlorosis but not of any other nutrient deficiency. The second and third orchards were irrigated in summer and managed with vegetation cover; the first and fourth orchards were rain fed and conventionally tilled. Thus, the orchards differed in cultivar, tree age, soil properties, and management in order to test the treatments in various environments.

Four soil samples per experimental orchard were collected at the depth where most roots were found $(0-25 \mathrm{~cm}$ in the 'Manzanilla' and 'Arbequina' and $15-40 \mathrm{~cm}$ in the 'Ocal' and 'Picual' orchards). The samples were air-dried and ground to pass a 2-mm sieve. The properties of the soils from the four experimental orchards are shown in Table 1. All soils were strongly calcareous with calcium carbonate equivalent content (CCE), determined by weight loss upon treatment with $6 \mathrm{M}$ $\mathrm{HCl}$, that ranged from 470 to $710 \mathrm{~g} \mathrm{~kg}^{-1}$ and active calcium carbonate equivalent or "active lime" (ACCE), determined by reaction with neutral $\mathrm{NH}_{4}$ oxalate, that ranged from 177 to $290 \mathrm{~g} \mathrm{~kg}^{-1}$. Clay content (Gee and Bauder 1986) ranged from 250 to $320 \mathrm{~g} \mathrm{~kg}^{-1}$ and organic carbon (dichromate oxidation) from 0.6 to $1.2 \mathrm{~g} \mathrm{~kg}^{-1}$. All $\mathrm{pH}$ values $(1: 2.5$ soil/water suspension) were above 7.8 , which is typical of calcareous soils, and electrical conductivity (1:5 soil/water suspension) was low $\left(<0.16 \mathrm{dS} \mathrm{m}^{-1}\right)$. Only the 'Picual' soil showed a low level $\left(7 \mathrm{mg} \mathrm{kg}^{-1}\right)$ in Olsen $\mathrm{P}$ (extraction with $0.5 \mathrm{M} \mathrm{NaHCO}_{3}$ buffered at $\mathrm{pH}$ 8.5; Olsen et al. 1954). The 'Manzanilla' was 
Table 1 Soil properties in the four experimental orchards

\begin{tabular}{|c|c|c|c|c|c|c|c|c|c|c|c|c|c|c|}
\hline Cultivar & $\begin{array}{l}\text { Depth } \\
\mathrm{cm}\end{array}$ & $\begin{array}{l}\text { Clay } \\
\mathrm{g} \mathrm{kg}^{-1}\end{array}$ & $\begin{array}{l}\text { Organic } \\
\text { carbon }\end{array}$ & $\mathrm{CCE}$ & ACCE & $\mathrm{pH}$ & $\begin{array}{l}\text { Electrical } \\
\text { conductivity } \\
\mathrm{dS} \mathrm{m}^{-1}\end{array}$ & $\begin{array}{l}\text { Olsen P } \\
\mathrm{mg} \mathrm{kg}^{-1}\end{array}$ & Available K & $\begin{array}{l}\mathrm{CEC} \\
\mathrm{cmol}_{(\mathrm{c})} \mathrm{kg}^{-1}\end{array}$ & $\begin{array}{l}\mathrm{Fe}_{\mathrm{d}} \\
\mathrm{g} \mathrm{kg}^{-1}\end{array}$ & $\mathrm{Fe}_{\mathrm{ox}}$ & $\mathrm{Fe}_{\mathrm{ca}}$ & $\begin{array}{l}\mathrm{Fe}_{\mathrm{DTPA}} \\
\mathrm{mg} \mathrm{kg}^{-1}\end{array}$ \\
\hline 'Manzanilla' & $0-25$ & 250 & 1.2 & 640 & 278 & 7.8 & 0.16 & 21 & 52 & 21.8 & 2.5 & 0.25 & 0.66 & 2.2 \\
\hline 'Arbequina' & $0-25$ & 300 & 1.2 & 470 & 177 & 8.1 & 0.16 & 29 & 250 & 23.4 & 4.6 & 0.50 & 0.95 & 4.0 \\
\hline 'Ocal' & $15-40$ & 320 & 1.0 & 480 & 218 & 8.5 & 0.12 & 19 & 188 & 25.4 & 3.9 & 0.43 & 0.86 & 4.5 \\
\hline 'Picual' & $15-40$ & 270 & 0.6 & 710 & 290 & 8.6 & 0.08 & 7 & 131 & 17.0 & 2.8 & 0.33 & 1.27 & 2.6 \\
\hline
\end{tabular}

All data are means of four samples

$C C E$ calcium carbonate equivalent, $A C C E$ active calcium carbonate equivalent (active lime), $C E C$ cation exchange capacity, $F e_{d}$ dithionite-extractable $\mathrm{Fe}, \mathrm{Fe}_{o x}$ oxalate-extractable $\mathrm{Fe}, \mathrm{Fe}_{c a}$ citrate/ascorbate-extractable $\mathrm{Fe}, \mathrm{Fe}_{D T P A}$ diethylenetriaminepentaacetic acid-extractable $\mathrm{Fe}$

low in available $\mathrm{K}$ (determined by extraction with $1 \mathrm{M}$ $\mathrm{NH}_{4} \mathrm{OAc}$ buffered at $\left.\mathrm{pH} 7\right)\left(52 \mathrm{~g} \mathrm{~kg}^{-1}\right)$. Cation exchange capacity (CEC) was medium (17-25.4 $\left.\mathrm{cmol}_{\mathrm{c}} \mathrm{kg}^{-1}\right)$. The value of acid oxalate-extractable $\mathrm{Fe}\left(\mathrm{Fe}_{\mathrm{ox}}\right)$, which was determined according to Schwertmann (1964) but using only $250 \mathrm{mg}$ of soil in $50 \mathrm{~mL}$ of extractant to keep $\mathrm{pH}$ close to 3, was below the critical level of $0.35 \mathrm{~g} \mathrm{~kg}^{-1}$ proposed by Benítez el al. (2002) for the 'Manzanilla' and 'Picual' but above it in the 'Arbequina' and 'Ocal' soils. The range in diethylenetriaminepentaacetic acid-extractable Fe (Fe DTPA; Lindsay and Norvell 1978) was 2.2-4.5 $\mathrm{mg} \mathrm{kg}^{-1}$, the 'Manzanilla' and 'Picual' soils being the ones with Fe DTPA $_{\text {Th }}$ below the critical level of $4 \mathrm{mg} \mathrm{kg}^{-1}$ proposed by Lindsay and Norvell (1978). These two soils were also the ones with the lowest citrate/bicarbonate/dithionite-extractable $\mathrm{Fe}\left(\mathrm{Fe}_{\mathrm{d}}\right.$; Mehra and Jackson 1960); however, the 'Picual' soil exhibited the highest citrate/ascorbate-extractable $\mathrm{Fe}\left(\mathrm{Fe}_{\mathrm{ca}}\right.$; Reyes and Torrent 1997).

\subsection{Experimental design and treatments}

A completely randomized block design with eight blocks (six for cv. Ocal) and one tree per plot was established in spring 2009 in the 'Manzanilla,' 'Arbequina,' and 'Ocal' orchards. A completely randomized design with six replications and one tree per plot was established in spring 2010 in the 'Picual' orchard.

The four experimental treatments consisted in injecting into the soil an equal volume of a suspension of siderite, a solution of Fe sulfate $\left(\mathrm{FeSO}_{4} \cdot 7 \mathrm{H}_{2} \mathrm{O}\right)$, a solution of $\mathrm{K}_{2} \mathrm{SO}_{4}$, or water. These treatments were designed as "Siderite," "Fe-sulfate," "Control-K," and "Control-0", respectively. The Control-0 treatment was only applied in the 'Ocal' and 'Picual' orchards.

The siderite suspension was prepared by dissolving $4.25 \mathrm{~kg}$ of $\mathrm{FeSO}_{4} \cdot 7 \mathrm{H}_{2} \mathrm{O}$ and $2.12 \mathrm{~kg}$ of $\mathrm{K}_{2} \mathrm{CO}_{3}$ ('Manzanilla' and 'Arbequina' orchards) or $4.50 \mathrm{~kg}$ of $\mathrm{FeSO}_{4} \cdot 7 \mathrm{H}_{2} \mathrm{O}$ and $2.25 \mathrm{~kg}$ of $\mathrm{K}_{2} \mathrm{CO}_{3}$ ('Picual' and 'Ocal' orchards) in $100 \mathrm{~L}$ of water. The resulting dark green suspension, which contained about 1.75 and $1.85 \mathrm{~kg}$ of siderite, respectively, was continuously stirred to keep the siderite particles in suspension. For the "Fe-sulfate" treatment, an amount of $\mathrm{FeSO}_{4} \cdot 7 \mathrm{H}_{2} \mathrm{O}$ equal to that used in the "Siderite" treatment plus an amount of $\mathrm{K}_{2} \mathrm{SO}_{4}$ aimed at supplementing the solution with $\mathrm{K}$ was used (1.00 kg for 'Manzanilla' and 'Arbequina' and $2.80 \mathrm{~kg}$ for 'Picual' and 'Ocal') in order to prepare $100 \mathrm{~L}$ of solution. For the "Control-K" treatment, only $\mathrm{K}_{2} \mathrm{SO}_{4}$ was used in equal amounts to those used in the corresponding " $\mathrm{Fe}$ sulfate" treatment.

In each orchard, the volume of the siderite suspension or diluted $\mathrm{Fe}$ sulfate solution applied to each tree was that corresponding to the $\mathrm{Fe}$ and $\mathrm{K}$ doses shown in Table 2. The suspensions of siderite and diluted Fe sulfate were injected into the soil immediately after preparation by means of a $\mathrm{T}$ shaped injector connected to the $100-\mathrm{L}$ tank in $0.5-2-\mathrm{L}$ portions at 5-15 points at a distance of 0.5 and $1.5 \mathrm{~m}$ from the tree trunk and a depth where root density was highest, i.e., about $15-35 \mathrm{~cm}$. In addition, the local olive growers applied to the soil about $0.5-1 \mathrm{~kg} \mathrm{~N}$ year ${ }^{-1}$ tree $^{-1}$ and potassium applied as foliar spray $\left(2.5 \% \mathrm{~K}_{2} \mathrm{SO}_{4}\right)$.

\subsection{Plant measurements and analysis}

In May, July, and October of each year, between 20 and 30 shoots of the current season were selected around each tree at about $150-180 \mathrm{~cm}$ above the soil surface, and one fully

Table $2 \mathrm{Fe}$ and $\mathrm{K}$ doses for the different experimental orchards and treatments

\begin{tabular}{|c|c|c|c|c|c|c|c|c|}
\hline \multirow[t]{2}{*}{ Treatment } & \multicolumn{2}{|c|}{ 'Manzanilla' } & \multicolumn{2}{|c|}{ 'Arbequina' } & \multicolumn{2}{|c|}{ 'Ocal' } & \multicolumn{2}{|c|}{ 'Picual' } \\
\hline & $\begin{array}{l}\mathrm{Fe} \\
\mathrm{g} \text { tree }\end{array}$ & $\mathrm{K}$ & $\mathrm{Fe}$ & $\mathrm{K}$ & $\mathrm{Fe}$ & $\mathrm{K}$ & $\mathrm{Fe}$ & K \\
\hline Control-0 & \multicolumn{2}{|c|}{ Not applied } & \multicolumn{2}{|c|}{ Not applied } & 0 & 0 & 0 & 0 \\
\hline Control-K & 0 & 90 & 0 & 90 & 0 & 630 & 0 & 380 \\
\hline Siderite & 170 & 240 & 170 & 240 & 450 & 630 & 300 & 380 \\
\hline Fe-sulfate & 170 & 90 & 170 & 90 & 450 & 630 & 300 & 380 \\
\hline
\end{tabular}


expanded leaf longer than $3 \mathrm{~cm}$ was collected from each shoot. The leaves were kept in a cool box and transported to the lab within the next $5 \mathrm{~h}$. Then, the leaves were weighted, and leaf chlorophyll concentration was estimated using the soil plant analysis development (SPAD) 502 portable chlorophyll meter (Minolta Camera, Osaka, Japan). To validate the use of the SPAD apparatus, 30 leaves with different degrees of $\mathrm{Fe}$ chlorosis were collected from each cultivar. In each leaf, SPAD readings were taken, and a piece of the middle of the leaf $\left(\sim 1 \mathrm{~cm}^{2}\right)$ was cut, weighed, and placed in a tube with $10 \mathrm{~cm}^{3}$ of methanol for $24 \mathrm{~h}$ in the dark. The absorbance of the extract was measured at $665 \mathrm{~nm}$ (chlorophyll $a$ ) and $650 \mathrm{~nm}$ (chlorophyll $b$ ), and the chlorophyll content per unit of leaf weight was calculated according to Holden (1976). SPAD units and leaf chlorophyll concentration per unit weight were highly correlated $(r=$ $0.91^{* * *}$ for 'Manzanilla', $r=0.94^{* * *}$ for 'Arbequina, $r=$ $0.89^{* * *}$ for 'Ocal', and $r=0.92^{* * *}$ for 'Picual'). Previous experiments with olive trees growing in the field had shown that SPAD units were strongly correlated with chlorophyll content (milligrams per square centimeter) (Benítez et al. 2002).

In the second half of July, 20 shoots of the previous year were randomly selected around the tree, and one leaf was taken from the central part of each shoot to analyze mineral element concentration. Leaves were washed with distilled water with $0.01 \%$ Tween 20 , dried at $60{ }^{\circ} \mathrm{C}$ for $70 \mathrm{~h}$ before grinding with a mill, and finally digested with nitric/perchloric acid (Zazoski and Burau 1977). Ca, Mg, Fe, Mn, Cu, and Zn in solution were determined by atomic absorption spectrophotometry, $\mathrm{K}$ by flame emission, and $\mathrm{P}$ with the molybdenum blue color method of Murphy and Riley (1962). The N concentration was determined by direct combustion of the plant material, using a EuroVector EA3000 Elemental Analyzer (EuroVector SpA, Milan, Italy).

The trunk perimeter $50 \mathrm{~cm}$ above the ground and canopy volume (estimated as the volume of a sphere with a mean diameter calculated from the height and two perpendicular diameters of the canopy) were measured at the beginning of October each year. Yield was recorded in the 2010-2012 period for the 'Picual' and in 2010 for the 'Ocal' orchard.

\subsection{Experimental oxidation of $\mathrm{Fe}$ salts in the laboratory}

Portions of $20 \mathrm{~cm}^{3}$ of siderite suspensions and $\mathrm{Fe}$ sulfate and $\mathrm{K}_{2} \mathrm{SO}_{4}$ solutions prepared as in the field (but using deionized water) were injected with a syringe into $50 \mathrm{~g}$ of the soil collected from each experimental orchard and placed in a cylindrical glass funnel. Then, the funnel was covered with punctured parafilm for $48 \mathrm{~h}$ to allow air exchange but not water loss. Then, the soil was removed from the funnel, airdried, ground, and $\mathrm{Fe}_{\mathrm{ox}}, \mathrm{Fe}_{\mathrm{ca}}$, and $\mathrm{Fe}_{\mathrm{DTPA}}$ determined as before. Then, a portion of the soil in each funnel was subjected to successive cycles of wetting (field capacity) and drying in a room at $24{ }^{\circ} \mathrm{C}$ and $\mathrm{Fe}_{\mathrm{ox}}, \mathrm{Fe}_{\mathrm{ca}}$, and $\mathrm{Fe}_{\mathrm{DTPA}}$ determined after three and ten of these cycles. This experiment was performed in duplicate for the different soil $\times$ treatment combinations.

\subsection{Statistical analyses}

The analysis of variance (ANOVA) was performed with Statistix 9.0 (Analytical Software, Tallahassee, FL, USA) and based on a randomized complete block design in three experimental orchards ('Manzanilla,' 'Arbequina,' and 'Ocal') with eight, eight, and six blocks, respectively, and completely randomized design in 'Picual' orchard with six replications. The experimental unit was one olive tree in all fields. Means were separated via the LSD test. Pearson correlation was used to relate measured variables. The word "significant" is used here to indicate significance at the $P<0.05$ level.

\section{Results and discussion}

\subsection{Plant performance}

At the beginning of the experiment, all trees exhibited symptoms of $\mathrm{Fe}$ chlorosis, and no significant differences in SPAD between the trees selected for the different treatments were observed. SPAD readings generally increased during the growing season (spring to autumn) because leaves become thicker and older, and it should be noted that SPAD is a transmittance measurement (data not shown). Potassium did not seem to influence SPAD, as evident from the absence of significant differences in SPAD between "Control-0" and "Control-K" trees in those orchards where both treatments were applied ('Ocal' and 'Picual'). Either siderite, Fesulfate, or both had a positive effect on SPAD that was significant at most times for 'Manzanilla' and 'Picual' and only in July 2009 for 'Arbequina' and May 2009 and 2012 for 'Ocal.' The mean SPAD values for each growing season and for the 3 or 4 years (Fig. 2, left) reflect a significant superiority of Fe-sulfate over siderite in the two orchards where $\mathrm{Fe}$ fertilizers demonstrated to be effective to alleviate chlorosis ('Manzanilla' and 'Picual'). The SPAD values of Fe sulfatefertilized trees were about 7 and $6 \%$ higher than those of control trees in 'Manzanilla' and 'Picual,' respectively. The SPAD values of siderite-fertilized trees were $4 \%$ higher than those of the control trees in 'Manzanilla.' Visual inspection showed that these increases were reflected in an improvement in the overall health of the tree.

As can be seen in Fig. 2 (right), mean leaf weight was positively influenced by the application of one or both $\mathrm{Fe}$ fertilizers in 'Manzanilla' and 'Picual' (two seasons) and 'Ocal' (one season) but not in 'Arbequina.' The mean leaf weight for the 2010, 2011, and 2012 seasons was significantly 


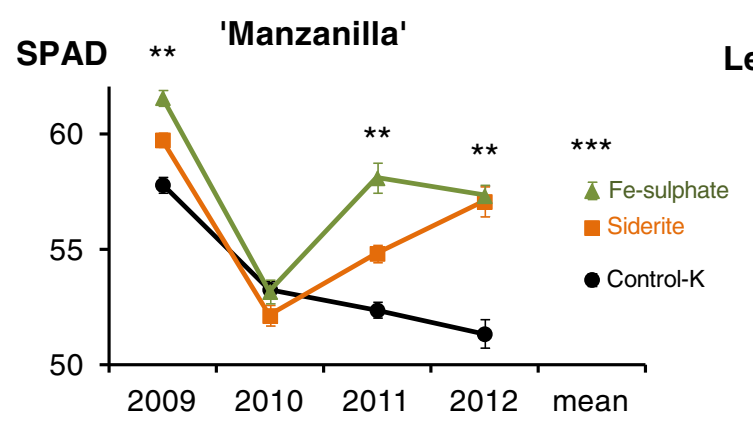

'Arbequina'
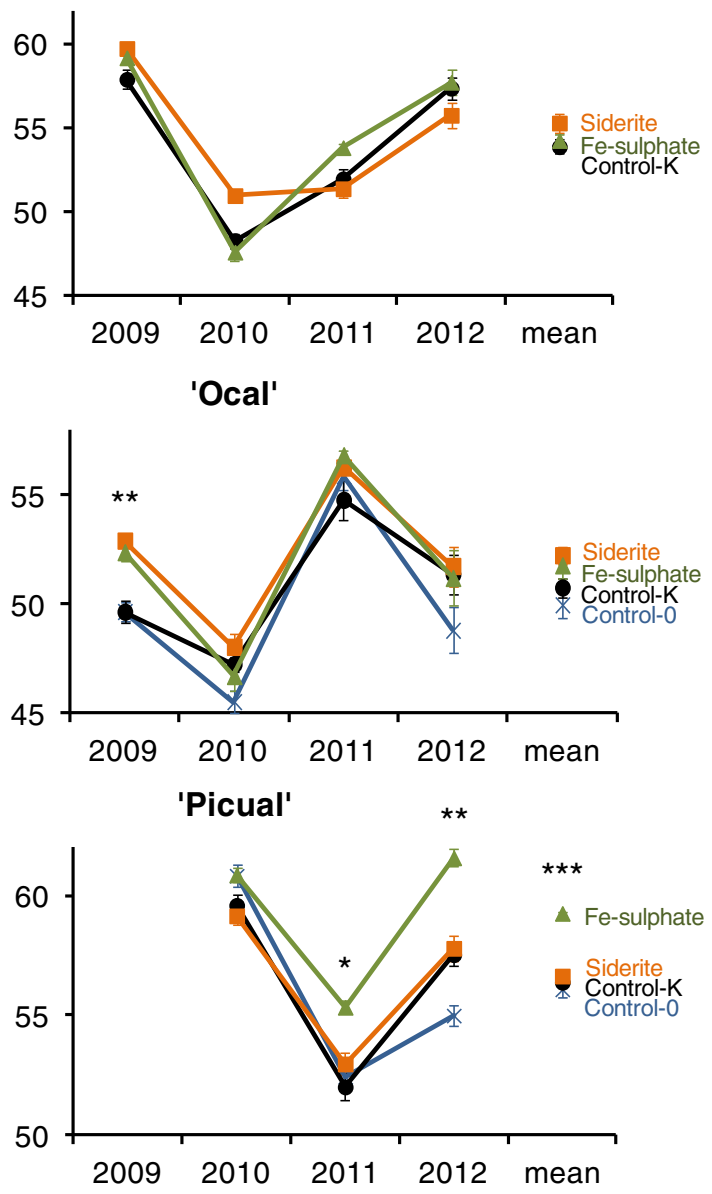

Fig. 2 Mean soil plant analysis development (SPAD) (left) and mean leaf weight (right) values for each cultivar growing season and mean for 3 of 4 years (mean \pm standard error, where absent, bars fall

influenced by both fertilizers in 'Manzanilla' and by siderite in 'Picual,' with an increase of 6-9 \% relative to the control trees. These results are thus in line with those on SPAD.

Fertilization with Fe had no significant effect on canopy volume, trunk perimeter, annual trunk perimeter increment, and cumulative yield (data not shown). Canopy volume and trunk perimeter were proportional to tree age, except in 'Ocal' because these trees were severely pruned during the experiment. Significant differences in yield were found in 2010 and 2012 (but not in cumulative yield) in 'Picual.'
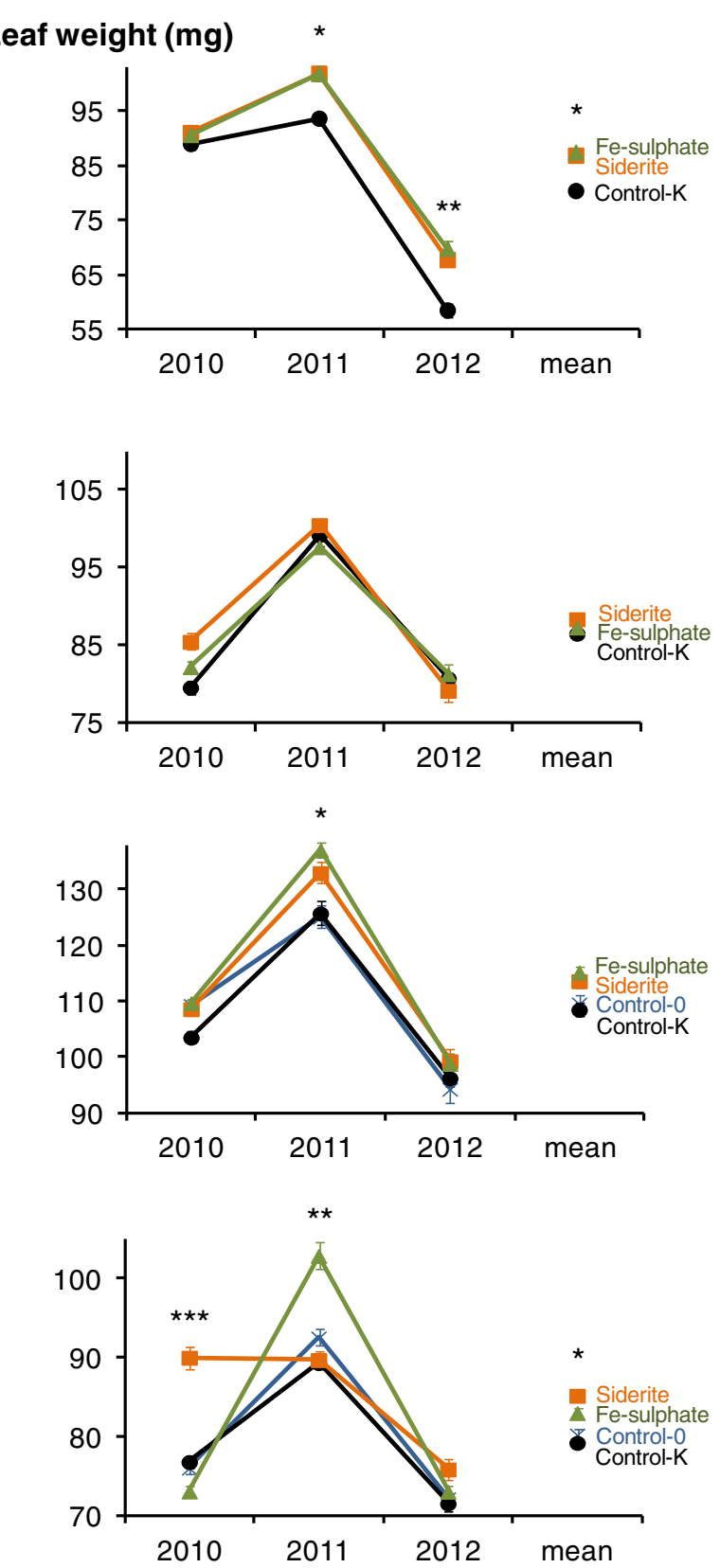

within symbols). *, **, and *** indicate $P<0.05,0.01$, and 0.001 , respectively. Blue line Control-0, black line Control-K, orange line Siderite, green line Fe-sulfate

Leaf mineral element concentrations (data not shown) were always above the critical levels compiled by FernándezEscobar (2008), except for $\mathrm{K}$ in 'Manzanilla' trees because the available $\mathrm{K}$ content of its soil was low $\left(52 \mathrm{~g} \mathrm{~kg}^{-1}\right)$. It should be noted that leaf $\mathrm{Mn}$ concentration in control trees in 2009, 2010, and 2011 for 'Manzanilla' and 2009 for 'Ocal' was significantly higher than that in trees fertilized with $\mathrm{Fe}$ because $\mathrm{Fe}$-deficient conditions increase the outflow of protons and the reducing capacity of root cells, thereby contributing to the reduction and dissolution not only of $\mathrm{Fe}$, 


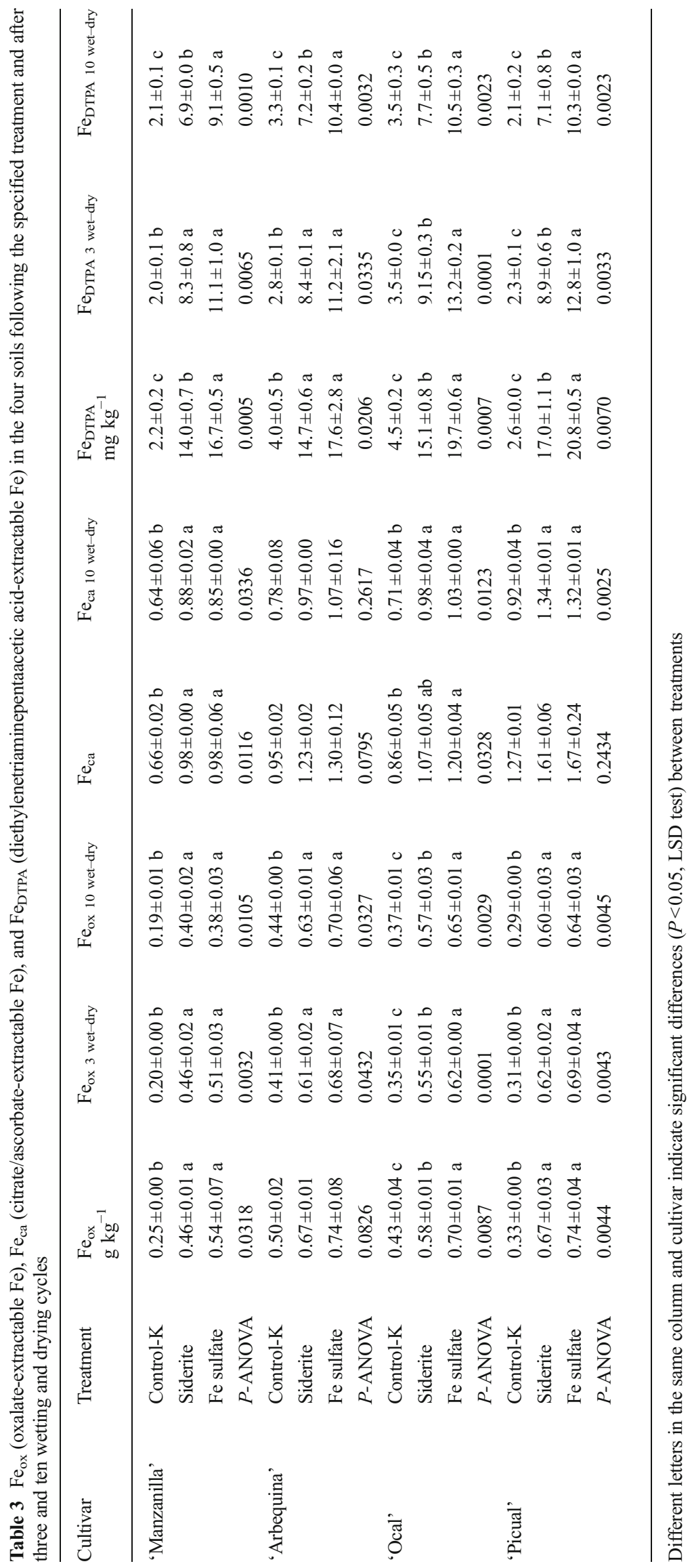


but also of Mn (Moraghan and Freeman 1978). No differences were found in leaf $\mathrm{Fe}$ concentration (which ranged from 19 to $80 \mathrm{mg} \mathrm{kg}^{-1}$ ) because this element can accumulate in leaves even under conditions of deficiency (a fact known as the "chlorosis paradox"; Römheld 2000).

\subsection{Changes in Fe forms in soil incubated with Fe fertilizers}

Table 3 shows the values of $\mathrm{Fe}_{\mathrm{ox}}, \mathrm{Fe}_{\mathrm{ca}}$, and $\mathrm{Fe}_{\mathrm{DTPA}}$ in the four soils incubated with siderite and Fe sulfate after the start of the experiment and three and ten (only ten for $\mathrm{Fe}_{\mathrm{ca}}$ ) cycles of wetting and drying. Upon addition of $\mathrm{Fe}, \mathrm{Fe}_{\mathrm{ox}}$ increased from 0.2 to $0.4 \mathrm{~g} \mathrm{~kg}^{-1}, \mathrm{Fe}_{\mathrm{ca}}$ from 0.2 to $0.4 \mathrm{~g} \mathrm{~kg}^{-1}$, and $\mathrm{Fe}_{\mathrm{DTPA}}$ from 11 to $18 \mathrm{mg} \mathrm{kg}^{-1}$. The ANOVA showed a significant effect of treatment on the amount of extractable $\mathrm{Fe}$ for all time $\times \mathrm{Fe}$ form combinations in the 'Manzanilla' and 'Ocal' soils, in five out of eight combinations in the 'Arbequina' soil, and seven out of eight combinations in the 'Picual' soil. The lack of significance occurred mostly for $\mathrm{Fe}_{\mathrm{ca}}$, probably because citrate/ascorbate is capable of extracting substantially more Fe than oxalate. Recovery of applied Fe generally decreased with the number of wetting and drying cycles, the effect being particularly marked for $\mathrm{Fe}_{\mathrm{DTPA}}$. Iron applied in the form of sulfate was generally more available to the different extractants than that applied in the form of siderite; this effect was particularly evident for $\mathrm{Fe}_{\mathrm{DTPA}}$ where significant evidences occurred in 9 out of 12 time $\times$ soil combinations.

\subsection{General discussion}

The results of this study demonstrated that siderite suspensions injected into the soil led in some cases to an alleviation of chlorosis symptoms, consistent with previous pot experiments with herbaceous crops (Sánchez-Alcalá et al. 2012a) and field experiments in olive orchards with other varieties of olive (Sánchez-Alcalá et al. 2012b). The latter experiments and the present study also indicate that the beneficial effect of a single application of siderite can persist for several growing seasons. This represents an advantage over the use of Fe chelates, which are easily washed from the soil. Siderite can be considered as a slow-release Fe fertilizer because it dissolves incongruently in soil to yield mainly poorly crystalline, small-sized lepidocrocite particles (Sánchez-Alcalá et al. 2012a), which cannot be washed and whose $\mathrm{Fe}$ is more phytoavailable than that of crystalline $\mathrm{Fe}$ oxides.

Iron sulfate has been used in different ways to prevent $\mathrm{Fe}$ chlorosis without positive persistent effects. Direct application to the soil surface is largely ineffective because it is rapidly oxidized and hydrolyzed to $\mathrm{Fe}$ oxides that are retained in the first few millimeters of the soil and are thus largely unavailable to the plant roots (Abadía et al. 2011). In the present study, the Fe sulfate solution was injected into a large volume of soil in the zone of greatest root density, and the $\mathrm{Fe}^{2+}$ ions could then react with the abundant calcite surfaces of these highly calcareous soils. This reaction would likely result in calcite being partly coated with lepidocrocite crystals as suggested by the experiments of Loeppert and Hossner (1984) and Clarke et al. (1985). This probably explains the superiority of $\mathrm{Fe}$ sulfate solutions over siderite suspensions because the lepidocrocite particles resulting from the alteration of siderite are concentrated where the initial siderite grain was and not distributed over the calcite surfaces as is the case with the Fe sulfate solutions. This obviously affects the number of Fe oxide particles that are close to the plant roots.

The different response of 'Manzanilla' and 'Picual' on one side and 'Arbequina' and 'Ocal' to the Fe fertilizers on the other was consistent with the $\mathrm{Fe}_{\mathrm{ox}}$ and $\mathrm{Fe}_{\mathrm{DTPA}}$ values of the corresponding soils. So, $\mathrm{Fe}_{\mathrm{ox}}$ and $\mathrm{Fe}_{\mathrm{DTPA}}$ in 'Manzanilla' and 'Picual' soils are below and the 'Arbequina' and 'Ocal' soils are close or above the respective critical values of $0.35 \mathrm{~g} \mathrm{Fe}_{\mathrm{ox}}$ $\mathrm{kg}^{-1}$ for olive (Benítez et al. 2002) and $4 \mathrm{mg} \mathrm{Fe} \mathrm{DTPA} \mathrm{kg}^{-1}$ for most crops (Lindsay and Norvell 1978). By contrast, $\mathrm{Fe}_{\mathrm{ca}}$ had little predictive value, even though the citrate/ascorbate reagent appears to extract the same forms of $\mathrm{Fe}$ as oxalate, specifically the poorly crystalline $\mathrm{Fe}$ oxides (Reyes and Torrent 1997). Another possible reason is that the two orchards where there was no response were those managed with vegetation cover. Graminaceous plants grown under $\mathrm{Fe}$ deficiency excrete phytosiderophores to the soil, which can bind $\mathrm{Fe}$ and constitute a good source of this element, as recent studies have demonstrated (Abadía et al. 2004).

Finally, it should be noted that the positive effect of $\mathrm{Fe}$ fertilizers on SPAD and leaf weight (Fig. 2) was not reflected in other plant growth parameters or oil yield. This can be explained by the lagged response of olive to nutrient stress because of built-up nutrient reserves, which are likely to increase with tree age.

\section{Conclusions}

Our results demonstrate the efficacy of siderite suspensions and clearly suggest the high potential of $\mathrm{Fe}$ sulfate solutions injected into the soil to increase $\mathrm{Fe}$ bioavailability in calcareous soils. Despite the scarce differences between Fefertilized and control trees, our results are consistent with our laboratory experiments. This calls for further research on the use of these Fe fertilizers, which have on the other hand the advantage of being readily prepared in a stirred tank and injected into the soil with a variety of devices. They are nontoxic and have no apparent adverse effects caused by the salinity of the solution. In addition, they are not susceptible to leaching because of the poor solubility of the Fe oxide phases resulting from their reaction with the soil. 
Acknowledgments This work was funded by the Spanish Ministry of Science and Innovation (Project AGL2008-0503-CO2-02 and Grant BES-2009-013598), as well as by the European Regional Development Fund. Some results of this work were obtained with cooperation from the SCAI of the University of Córdoba. The authors wish to thank F. Díaz (Gilena), R. Sánchez de Puerta (Aldea Quintana), and M.I. Lasheras (Baena) for their help in establishing the experimental orchards.

\section{References}

Abadía J, Álvarez-Fernández A, Rombolá AD, Sanz M, Tagliavini M, Abadía A (2004) Technologies for the diagnosis and remediation of Fe deficiency. Soil Sci Plant Nutr 50:965-971. doi:10.1080/ 00380768.2004.10408562

Abadía J, Vázquez S, Rellán-Álvarez R, El-Jendoubi H, Abadía A, Álvarez-Fernández A, López-Millán AF (2011) Towards a knowledge-based correction of iron chlorosis. Plant Physiol Biochem 49:471-482. doi:10.1016/j.plaphy.2011.01.026

Alcántara E, Cordeiro AM, Barranco D (2003) Selection of olive varieties for tolerance to iron chlorosis. J Plant Physiol 160:1467-1472. doi: 10.1078/0176-1617-01013

Álvarez-Fernández A, García-Laviña P, Fidalgo J, Abadía J, Abadía A (2004) Foliar fertilization to control iron chlorosis in pear (Pyrus communis L.) trees. Plant Soil 263:5-15. doi:10.1023/B:PLSO. 0000047717.97167.d4

Benítez ML, Pedrajas VM, del Campillo MC, Torrent J (2002) Iron chlorosis in olive in relation to soil properties. Nutr Cycl Agroecosyst 62:47-52. doi:10.1023/A:1015116732580

Clarke ET, Loeppert RH, Ehrman JM (1985) Crystallization of iron oxides on calcite surfaces in static systems. Clay Clay Miner 33: 152-158. doi:10.1346/CCMN.1985.0330210

de Santiago A, Delgado A (2006) Predicting iron chlorosis of Lupinus albus L. in calcareous Spanish soils from various iron extracts. Soil Sci Soc Am J 70:1945-1950. doi:10.2136/sssaj2005.0343

del Campillo MC, Torrent J (1992) Predicting the influence of iron chlorosis in calcareous soils of southern Spain. Commun Soil Sci Plant Anal 23:399-416. doi:10.1080/00103629209368598

Díaz I, Barrón V, del Campillo MC, Torrent J (2010) Testing the ability of vivianite to prevent iron deficiency in pot-grown grapevine. Sci Hortic 123:464-468. doi:10.1016/j.scienta.2009.11.006

Fernández-Escobar R (2008) Fertilización. In: Barranco D, FernándezEscobar R, Rallo L (eds) El cultivo del olivo, 6th edn. Mundi-Prensa and Junta de Andalucía, Madrid, pp 237-258

Gee GW, Bauder JW (1986) Particle-size analysis. In: Klute A (ed) Methods of soil analysis. Part 1. Physical and mineralogical methods. Agronomy monograph N. 9, 2nd edn. ASA/SSSA, Madison, pp 383-411

Holden M (1976) Chlorophylls. In: Goodwin TW (ed) Chemistry and biochemistry of plants pigments. Academic Press Inc, London, pp 1-37

Lindsay WL, Norvell WA (1978) Development of a DTPA soil test for zinc, iron, manganese and copper. Soil Sci Soc Am J 42:421-428. doi:10.2136/sssaj1978.03615995004200030009x
Loeppert RH, Hallmark CT (1985) Indigenous soil properties influencing the availability of iron in calcareous soils. Soil Sci Soc Am J 49: 597-603. doi:10.1080/01904168409363182

Loeppert RH, Hossner LR (1984) Reactions of $\mathrm{Fe}^{2+}$ and $\mathrm{Fe}^{3+}$ with calcite. Clay Clay Miner 32:213-222

Lucena JJ (2006) Synthetic iron chelates to correct iron deficiency in plants. In: Abadía J, Barton LL (eds) Iron nutrition and interactions in plants. Springer, Dordrecht, pp 103-128

Mehra OP, Jackson ML (1960) Iron oxide removal from soil and clays by dithionite-citrate systems buffered with sodium bicarbonate. Clay Clay Miner 7:317-327

Moraghan JT, Freeman TJ (1978) Influence of FeEDDHA on growth and manganese accumulation in flax. Soil Sci Soc Am J 42:455-460. doi:10.2136/sssaj1978.03615995004200030016x

Murphy J, Riley JP (1962) A modified single solution method for the determination of phosphate in natural waters. Anal Chim Acta 27: 31-36. doi:10.1016/S0003-2670(00)88444-5

Olsen SR, Cole CV, Watanabe FS, Dean LA (1954) Estimation of available phosphorus in soils by extraction with sodium bicarbonate. US Dep. of Agric. Circ. 939

Reyes I, Torrent J (1997) Citrate-bicarbonate as a highly selective extractant for poorly crystalline iron oxides. Soil Sci Soc Am J 61: 1647-1654. doi:10.2136/sssaj1997.03615995006100060015x

Roldán R, Barrón V, Torrent J (2002) Experimental alteration of vivianite to lepidocrocite in a calcareous medium. Clay Miner 37:709-718. doi: $10.1180 / 0009855023740072$

Römheld V (2000) The chlorosis paradox: Fe inactivation in leaves as a secondary event in Fe deficiency chlorosis. J Plant Nutr 23:1629 1643. doi:10.1080/01904160009382129

Rosado R, del Campillo MC, Martínez MA, Barrón V, Torrent J (2002) Long-term effectiveness of vivianite in reducing iron chlorosis in olive trees. Plant Soil 241:139-144. doi:10.1023/ A:1016058713291

Sánchez-Alcalá I, del Campillo MC, Barrón V, Torrent J (2012a) Pot evaluation of synthetic nanosiderite for the prevention of iron chlorosis. J Sci Food Agric 92:1964-1973. doi:10.1002/ jsfa.5569

Sánchez-Alcalá I, Bellón F, del Campillo MC, Barrón V, Torrent J (2012b) Application of synthetic siderite $\left(\mathrm{FeCO}_{3}\right)$ to the soil is capable of alleviating iron chlorosis in olive trees. Sci Hortic 138: 17-23. doi:10.1016/j.scienta.2012.02.001

Schwertmann U (1964) Differenzierung der Eisenoxide des Bodens durch Extraktion mit Ammoniumoxalat-Lösung. Z Pflanzenernähr Bodenkd 105:194-202. doi:10.1002/jpln.3591050303

Tagliavini M, Rombolà A (2001) Iron deficiency and chlorosis in orchard and vineyard ecosystems. Eur J Agron 15:71-92. doi:10.1016/ S1161-0301(01)00125-3

Tagliavini M, Abadía J, Rombolà AD, Abadía A, Tsipouridis $\mathrm{C}$, Marangoni B (2000) Agronomic means for the control of iron deficiency chlorosis in deciduous trees. J Plant Nutr 23:20072022. doi:10.1080/01904160009382161

Zazoski RJ, Burau RG (1977) A rapid nitric-perchloric acid digestion method for multielement tissue analysis. Commun Soil Sci Plant Anal 3:425-436. doi:10.1080/00103627709366735 